\title{
Effect of different levels of fish oil and canola oil on productive performance of early lactating Holstein dairy cows
}

T Sadat Vafa, A A Naserian, A R Heravi Moussavi, R Valizadeh, M Danesh Mesgaran, M Ali Khorashadizadeh Excellence Centre for Animal Science, Faculty of Agriculture, Ferdowsi University of Mashhad, Mashhad, Khorasan Razavi, Islamic Republic of Iran

Email:vafatoktam@yahoo.com

Introduction Lactation in the dairy cow is characterized by a dramatic increase in the nutrient demands for milk synthesis that coincides with a prepartum decline in dry matter intake (DMI) which leads to negative energy balance in early lactation. Supplemental fat sources are utilized in rations for dairy cows as a common method to increase the energy density of the diet or to modify milk production, milk fat content and milk fatty acids profile (Juchem et al., 2008); However, its effects depend on the digestibility of the fat sources and effects of supplemented fat on other diet component digestibility. It is well recognized that feeding vegetable oils containing unsaturated fatty acids inhibit ruminal fermentation, decreased dry matter intake (Harvatine and Allen, 2006b) and fibre digestibility especially in high concentrate diets. The current study was designed to evaluate the effect of fish oil and canola oil supplemented diets on DMI, nutrient digestibility and nutrient intake in high producing dairy cows in early lactation.

Material and methods Eight multiparous early lactation Holstein cows ( $42 \pm 12 \mathrm{DIM}, 40 \pm 6 \mathrm{~kg}$ daily milk yield) were fed a total mixed ration supplemented with either $0 \%$ oil (Control), $2 \%$ canola oil (CO), $2 \%$ fish oil (FO), or $1 \%$ canola oil $+1 \%$ fish oil (COFO), according to a double $4 \times 4$ Latin square design with four treatments, four periods, and two cows per treatment as the main plot, and the four sampling periods as the subplot. Each period lasted $21 \mathrm{~d}$, which included a 14-d diet adjustment period followed by a sampling period. Oils were added at a level of about $2 \%$ of dietary DM, resulting in a dietary ether extract content of $4.7 \%$. TMR mixture and faeces were sampled on first 5 days of each sampling period and were stored at $-20^{\circ} \mathrm{C}$. At the end of each period feed and faeces samples were mixed to get the final sample and were stored at $-20^{\circ} \mathrm{C}$ up to the end of experiment. Finally all the feed and faeces samples were dried in a forced-air oven at $60^{\circ} \mathrm{C}$, and stored in sealed plastic containers at room temperature until analyzed. In preparation for analyses, dried feed and faeces were ground first through a 2-mm screen and were analyzed for fat, ADF (Robertson and Van Soest, 1981), NDF (Van Soest et al., 1991), and CP (AOAC, 1990; method no. 988.05), acid-insoluble ash(AIA) (Van Keulen and Young, 1977). AIA content of feed and faeces was used as a natural marker in ruminant to determine apparent digestibility of some nutrient, using following formula:

Apparent digestibility $(\%)=100-[100 \times($ feed AIA $(\%) /$ faeces AIA $(\%)) \times($ feed nutrient $(\%) /$ faeces nutrient $(\%))]$ Data were analyzed as a replicated $4 \times 4$ Latin square using generalized linear model (PROC GLM, SAS Inst, Inc., Cary, NC).

Results The effects of supplementing diets with fish oil and canola oil on nutrient intake and digestibility are presented in Table1. DMI and organic matter (OM) intake decreased in FO diet and fat intake increased in all oil supplemented diets $(\mathrm{P}<0.05)$. OM and NDF digestibility decreased in FO diets $(\mathrm{P}<0.05)$.

Table 1 The effect of diets on nutrient intake, nutrient digestibility for lactating dairy cows

\begin{tabular}{|c|c|c|c|c|c|c|}
\hline \multirow[t]{2}{*}{ Parameter } & \multicolumn{4}{|c|}{ Treatments $^{1}$} & \multirow[t]{2}{*}{ SEM } & \multirow[t]{2}{*}{$\mathrm{p}$} \\
\hline & Control & FO & FOCO & $\mathrm{CO}$ & & \\
\hline \multicolumn{7}{|l|}{ Intake, $\mathrm{Kg} / \mathrm{d}$} \\
\hline $\mathrm{DM}$ & $24.92^{\mathrm{a}}$ & $22.21^{\mathrm{b}}$ & $24.61^{\mathrm{a}}$ & $24.86^{\mathrm{a}}$ & 0.61 & 0.04 \\
\hline OM & $23.19^{\mathrm{a}}$ & $19.89^{b}$ & $21.07^{\mathrm{a}}$ & $21.91^{\mathrm{a}}$ & 0.57 & 0.05 \\
\hline NDF & 7.98 & 7.06 & 7.45 & 7.96 & 0.45 & 0.43 \\
\hline $\mathrm{ADF}$ & 4.76 & 4.05 & 4.30 & 4.43 & 0.24 & 0.33 \\
\hline Fat & $0.79^{\mathrm{a}}$ & $0.98^{\mathrm{b}}$ & $1.18^{\mathrm{b}}$ & $1.12^{\mathrm{b}}$ & 0.01 & $<0.0001$ \\
\hline \multicolumn{7}{|l|}{ Digestability } \\
\hline $\mathrm{OM}$ & $65.58^{\mathrm{a}}$ & $60.62^{b}$ & $62.98^{\mathrm{a}}$ & $62.33^{\mathrm{a}}$ & 1.05 & 0.04 \\
\hline NDF & $61.81^{\mathrm{a}}$ & $51.55^{\mathrm{b}}$ & $52.22^{\mathrm{a}}$ & $53.89^{\mathrm{a}}$ & 2.52 & 0.04 \\
\hline $\mathrm{ADF}$ & 43.63 & 42.11 & 42.42 & 43.72 & 1.05 & 0.19 \\
\hline Fat & 65.43 & 77.76 & 69.57 & 74.9 & 3.83 & 0.16 \\
\hline
\end{tabular}

Conclusion Results of the current experiment reveals that supplementing diet with fish oil had significant effects on intake and digestibility of some nutrient, but combing fish oil with plant oil will reduce their adverse effects. Strong negative effects of linseed oil on ruminal fibre digestibility with high proportion of concentrate in diet (67\% in DM basis) were reported previously (Ueda et al., 2003).

\section{References}

Harvatine, K. J and M. S. Allen. 2006. Journal of Dairy Science 89, 1092-1103.

Juchem, S. O, J.E.P. Santos, R.L.A. Cerri, R.C. Chebel, K.N. Galvªo, R. Bruno, E.J. DePeters, T. Scott, W.W. Thatcher and D. Luchini. 2008. Animal Feed Science and Technology. 140,18-38.

Ueda, K, A. Ferlay, J. Chabrot, J. J Loor, Y. Chilliard and M. Doreau. 2003. Journal of Dairy Science. 86,3999-4007. 